Mater. Res. Soc. Symp. Proc. Vol. 1432 @ 2012 Materials Research Society DOI: 10.1557/opl.2012.1486

\title{
Erratum
}

\section{Ga-vacancy Activation Under Low Energy Electron Irradiation in GaN-based Materials - ERRATUM}

Henri Nykänen, Sami Suihkonen, Lucasz Kilanski, Markku Sopanen, and Filip Tuomisto

doi: 10.1557/opl.2012.782, Published by Cambridge University Press, 13 April 2012.

The acknowledgment that follows should have been included in the published article:

\section{THE CORRECTION}

This article was originally published on June 2012 with a mistake. The name of the third author was incorrect. The correct name of the third author is "Lukasz Kilanski."

The authors regret the error.

\section{Reference}

Henri Nykänen, Sami Suihkonen, Lucasz Kilanski, Markku Sopanen, and Filip Tuomisto: Ga-vacancy Activation Under Low Energy Electron Irradiation in GaN-based Materials, in Reliability and Materials Issues of III-V and II-VI Semiconductor Optical and Electron Devices and Materials II, edited by O. Ueda, M. Fukuda, K. Shiojima, and E. Piner (Mater. Res. Soc. Symp. Proc. 1432, Warrendale, PA, 2012). 